\title{
PARENTS PERSPECTIVE ON TRANSLATION QUALITY OF CHILDREN BILINGUAL STORYBOOKS
}

\author{
Dina Maharani ${ }^{1}$, Chusna Apriyanti ${ }^{2}$, Agustina Sri Hafidah ${ }^{3}$ \\ STKIP PGRI Pacitan, Pacitan, Indonesia
}

dinamah4599@gmail.com, chusna.apriyanti@gmail.com, hafidahagustinasri@yahoo.co.id

Submitted: 03/July/2021

Accepted: 12/July/2021

Publication: 01/Agustus/2021

\begin{abstract}
Parents believe that bilingual storybooks for children can be used as media for children in learning English. However, not all bilingual books have good quality in their translation. This research aims to know the parents' perspective on the quality of translation in children's bilingual storybooks. This is descriptive quantitative research. The data were gathered by using a questionnaire through implementing Google Form for 52 parents as respondents. Some considerations in choosing the respondents were applied, such as the parents have kindergarten and elementary schools level students and the parents use bilingual storybooks at home. The storybooks in this research consist of English and Indonesia, with Bahasa Indonesia as the source language and English as a target language. The research was conducted from April to June 2021. After being collected, the data are presented as the data display stage, and the researchers conclude. The result shows that there are 48 parents of 52 parents who consider bilingual storybooks as media. Fifty parents also buy bilingual storybooks for their children. Among the respondents, 37 parents check the language of the books, and 15 parents do not match. Forty-two parents believe that the books are qualified for learning English. There are five considerations for parents in buying books: story, picture, language, price, and publishers/authors.
\end{abstract}

Keywords: Bilingual Book, Children Storybook, Learning English, Parents, Translation Quality

\section{Introduction}

English is the third most spoken language globally, with 370 million native English speakers and 978 million people who speak it as a second language, where Chinese is the first and Spanish is the second (Lane, 2021). It implies that English becomes the language of travel, the internet, business, and international relations. By this fact, having English skills is urgently needed in this era.

Some people believe that learning English is effective starting from an early age. They will learn a foreign language better than older learners in the ultimate attainment, though they are regarded as fast and efficient language learners (Hu, 2016). The study found that age affects EFL learning because early exposure to language instructions constantly results in better performance. The research shows that start learning English at an earlier age is an essential factor in enhancing the skills of English language learners (Gawi, 2012). The primary motivation for these early starts is the assumption that 'earlier is better. In other words, the age of acquisition is an essential and robust predictor of foreign language learning success (Chen et al., 2020).

Languages learned informally before the age of six are generally mastered with nativelike proficiency, whereas those learned in adolescence and adulthood will rarely attain a nativelike level (Hamers \& Blanc, 2002). Learning English as a foreign language at an early age 
improves the communicative competence in that foreign language, but it also helps to understand better their mother tongue (Blázquez, 2016). Teaching English at the primary level provides children more opportunities to understand foreign cultures and be more tolerant of others (Cahyati \& Madya, 2019).

However, it is still debatable among scholars. There is no fine line in determining whether exposing children to language early or late brings more success. Learning a language early often leads to higher language proficiency, but it does mean that they are better than late language learners (Hakiki \& Hidayati, 2017). We may argue that in terms of acquiring nativelike pronunciation, an early start may give some advantages. Nevertheless, in terms of other aspects of acquisition, any positive correlation of age was not found (Rahman et al., 2017).

The assumption of better learning at an early age leads parents to supply English skills for their kids. Parents also believe that English is the first foreign language in Indonesia, and the learning process must be carried out in stages (Khairani, 2016). An interview with 40 parents was conducted. The results showed that 80\% (32 parents) believed that acquiring English in early childhood was very important and needed to be taught early (Nurjaman et al., 2020). Hurlock (1993) states that elementary school children can understand a foreign language and understand the mother's language in 4 language skills: listening, speaking, reading, and writing (Niah et al., 2017). There are two significant reasons for an early start in English: the value of English for education and employment and the benefits of early language learning (Raman et al., 2011)

Teaching English to children has specific characteristics. Compared to adults, children are more energetic, have shorter attention spans, and learn language according to specific stages of development; these present planning challenges for the teacher (Hashemi \& Azizinezhad, 2011). Teaching and learning English in elementary school provides the students' English language competencies in the golden age -the age that children can learn anything quickly (Sukarno, 2012). Several characteristics of children, such as able to talk about what they are doing, they tell what they have done or heard, they can plan activities, argue for something and tell you why they think what they think, use logical reasoning, use their vivid imaginations, use a wide range of intonation patterns in their mother tongue, and can understand direct human interaction (Gautam, 2015).

There are many strategies used to teach English to children. The materials may include EFL textbooks, worksheets, audio-visual recordings, picture books and poems, drama, and stories for oral delivery (Bland, 2019). The importance of using the most appropriate methodologies when teaching English as a Second Language must be undoubtedly emphasized (Rey et al., 2017). Kids get quickly involved in different activities and games and ask to play them repeatedly (Achkasova, 2013). The findings highlight that the use of opportunities provided by the teachers and effective strategies such as repetition, bilingual use, and parallel talk can increase English interaction among preschool children (Mustafa \& Ahmad, 2017).

Leaming materials for TEYL are everywhere. It can take the form of course book materials or supplementary materials (Diyanti, 2016). The younger children seemed to prefer the books that presented information in a narrative (books by Taylor and Harris) though books with colorful photos seemed favored by all (Glazer et al., 2017). Bilingual books can play an essential part in supporting ESL students' language and literacy learning (Ernst-Slavit \& Mulhern, 2003).

The existence of bilingual storybooks for children is widely developed across the country. It is easily found in a bookstore. The school's library also supplies the collection with children's bilingual storybooks. The sense of colorful pictures and stories attracts the children to learn, even the parents to buy. They admit that their children can learn English through those books. Day by day, the spread of books reaches its market. Many publishers produce these kinds of books.

However, parents who have no English skills will trust that books as learning media for their children. Without rechecking the quality, they bring those books to their kids. The consideration of the price and the story becomes their reasons to buy. This research tries to reveal this problem. There is a lot of research discussing the quality of bilingual short storybooks for children. They deal with meaning inaccuracies and grammatical problems. Those 
research do not find out why parents love bilingual books and admit it as an essential tool for learning. However, the research about translation errors must be done to increase parents' awareness in chosing bilingual books for their children.

\section{Research Method}

This is descriptive quantitative research. The data were gathered by using a questionnaire through implementing Google Form for 52 parents as respondents. Some considerations in choosing the respondents were applied, such as the parents have kindergarten and elementary schools level students and the parents use bilingual storybooks at home. The storybooks in this research consist of English and Indonesia, with Bahasa Indonesia as the source language and English as a target language. The research was conducted from April to June 2021. After being collected, the data are presented as the data display stage, and the researchers conclude.

\section{Results and Discussion}

\section{Parents Attitude to Choose Bilingual Storybook as Learning Media}

Parents seem to use bilingual storybooks as learning media at home. From the research result, 48 parents consider bilingual storybooks as media. However, four parents do not only use bilingual storybooks as learning media. They use it as the children's collection for reading and focus on the story.

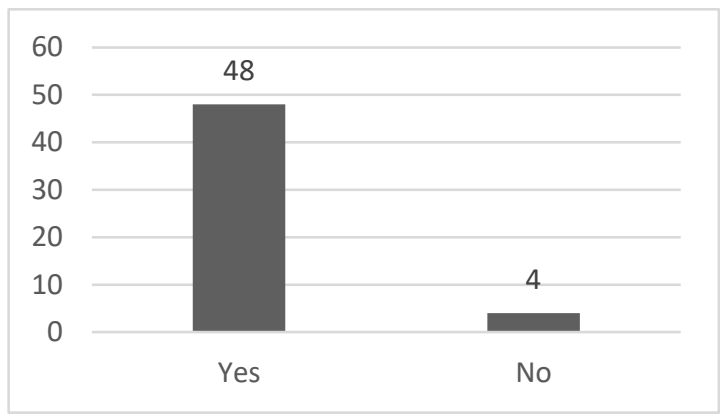

Figure 1: Parents' Attitude to Choose Bilingual Storybook as Learning Media Parents' Attitude in Buying Bilingual Storybooks for their Children

Most of the parents buy their children bilingual books. From 52 parents, 50 parents buy bilingual books for their children. Two parents do not buy a bilingual book, but their children borrow the bilingual books from the school library. The findings can be seen in the following chart:

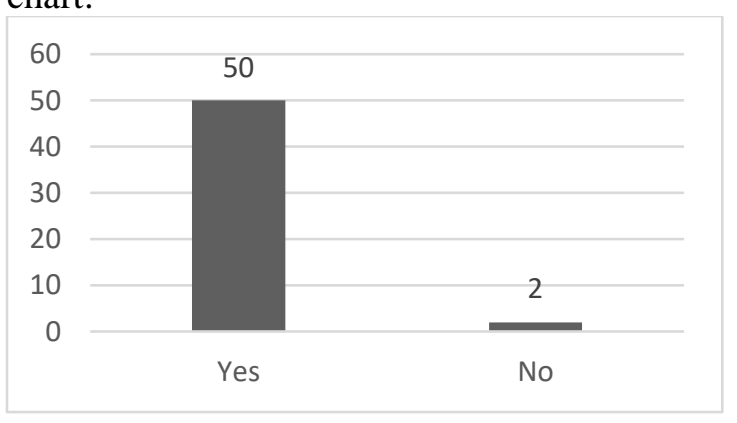

Figure 1: Parents' Attitude in Buying Bilingual Storybooks for their Children Parents' Belief on the Quality of Children Bilingual Storybooks

Since bilingual storybooks consist of two languages, Bahasa Indonesia as the source language and English as the target language, the parents do not check the quality of translation. Thirty-seven parents believe that bilingual storybooks consist of correct grammar and meaning even though they check the quality. The rest, 15 parents, do not check the quality. They just buy the book and lead the children to read it. However, they sometimes read both the text, the English and Bahasa Indonesia. They read all the sentences written in the book without checking 
the quality of the English version. However, they do not know whether the English translation is accurate to the source text or not. They do not know whether the sentence written in English is true or not, both in grammar and in context.

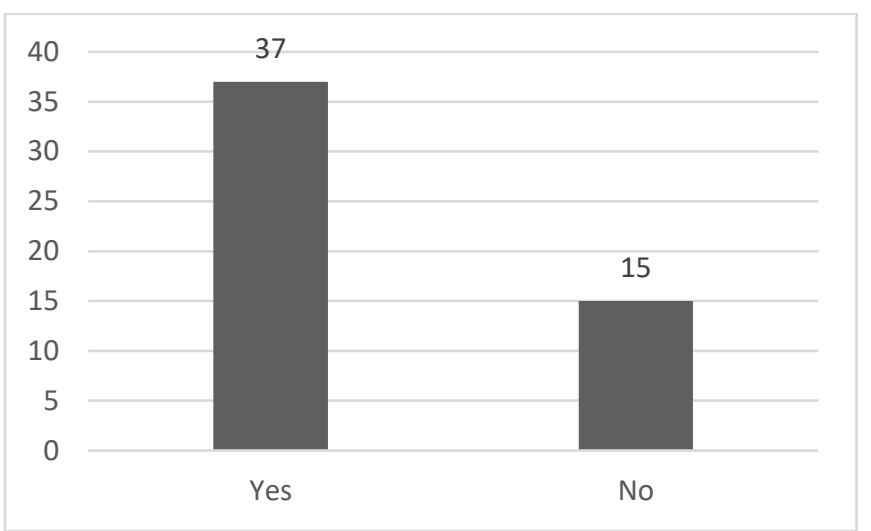

Figure 3. Parents' Attitude in Checking on the Quality of Children Bilingual Storybooks

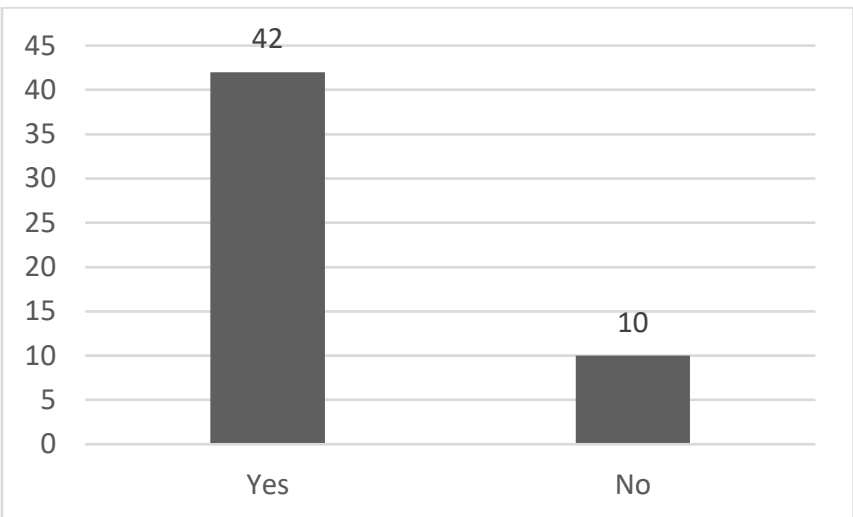

Figure 4: Parents' Belief's on the Quality of Bilingual Children Storybook

Parents have a firm belief and expectation of the quality of children's bilingual storybook. However, they do not check the language written inside, both Bahasa Indonesia and English. Forty-two parents believe that the books are qualified and fit their children's learning media. However, ten parents do not have a firm belief in the quality of bilingual children's storybooks.

Finding out parents' consideration in buying bilingual books, most parents consider the story as the main reason for buying books, as presented in this picture.

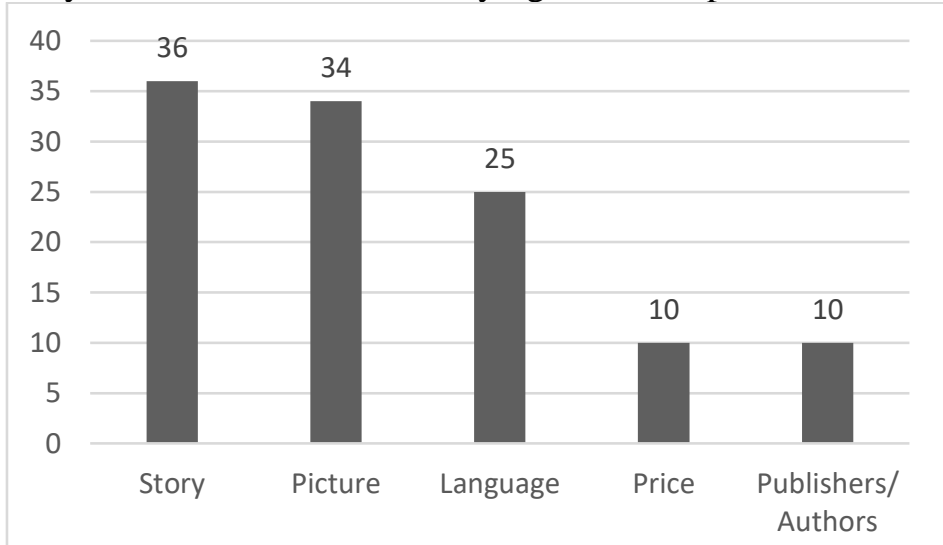

Figure 5: Parents' Considerations in Choosing Bilingual Books

In this instrument, parents were asked to choose two reasons for buying books. The majority of parents admit the story as the main reason, followed by the picture. Language is placed in the third rank of reasons. It implies that the visual appearance of books is the magnet 
for them. Price is also listed in the considerations while publishers and authors do not play an essential point for parents. They buy books even though they do not know the authors or the publishers.

Learning English among children becomes a trend nowadays. Some parents argue that they support their children to learn English. However, in public schools, especially in Pacitan, children do not learn English because the K-13 curriculum eliminates English as the subject taught in school. Even though some private schools still supply their students with English material. Some parents also send the children to English courses. Another way is using bilingual storybooks as learning media at home.

Implementing bilingual books for children has two benefits: learning English and improving their language literacy during the reading story. The existence of bilingual books is extensive. However, the high expectation on the benefit of a bilingual storybook as learning media needs to guide by parents, especially for kindergarten students who still cannot read. Besides, children will tend to read the Bahasa Indonesia version due to language comprehension. However, the firm belief and number of parents who buy bilingual books for children do not significantly affect children's English language ability if they do not motivate them to read English. The number of bilingual books at home also does not represent the children's ability in English. Still, parents play an essential part in developing children's language. However, this is already good to start introducing English to children.

Bilingual books are widely spread in Indonesia. However, not all of the books have good quality. Since translation quality must cover two sides, grammar and meaning, both must fulfill the excellent quality of translation. There were six grammar errors in the bilingual short story: S-V agreement (19 sentences or 17,43\%), missing verb (52 sentences or $47.71 \%$ ), double verb (10 sentences or $9.17 \%)$, missing subject ( 5 sentences or $4.53 \%)$, parallel structure (10 sentences or $9.17 \%$ ) and pronoun (13 sentences or $11.93 \%)$. From the total of 320 sentences, the ungrammatical sentences are $39.69 \%$ or 127 sentences. It indicates that almost all of the books contain grammar errors (Rahayu \& Apriyanti, 2015).

The data in the previous paragraph implies that the quality of bilingual storybooks for children is questionable. Imagining these books become the sources of learning for children is dramatic because they can learn from the wrong sources. It is aggravated by the condition that not all parents have English skills. However, the children will learn English without the control from parents. Even the parents do not know if their learning sources are not suitable for learning.

It is supported by the data that most parents do not check the quality of English translation in their children's bilingual books. They have high trust related to the quality of translation. However, the high spirit of parents in supplying material for learning English must be directed to qualified media. The research related to the quality of bilingual stories for children should not be kept as an article in academic journals because of the limited range of readers. The mothers will not open and read academic journals unless they are teachers or lecturers. It implies that the research result does not solve the problem in society. That research must be published in mass media or social media to understand parents that not all bilingual books have good quality for learning English. The parents should select qualified storybooks for children as media for learning.

The publishers, especially the editors, also need to revise and check their translators' projects. Don't let the excellent spirit of parents to buy books for their children plunge them into learning because they learn from the wrong sources. The translators also have a high responsibility to fulfill qualified translation text as the main message that bilingual books for children do not play as reading books and learning media.

\section{Conclusion}

Most of the parents use bilingual books for children as learning English media. Most of them also buy those books for their children. But, parents do not consider the translation quality. Translation quality happens due to their limited English skills. Most of them believe that the quality of bilingual storybooks is good. There are five considerations for parents in buying 
books: story, picture, language, price, and publishers/authors.

\section{References}

Achkasova, N. (2013). The Best Ways of Teaching English to Children: Using Children's Operas in Teaching to 5- to 6-Year-Old Children. Online Submission, 3(6), 385-390.

Bland, J. (2019). Teaching English to Young Learners: More Teacher Education and More Children's Literature! Online Submission, 7(2), 79-103.

Blázquez, P. (2016). The benefits of learning a second language. 3-5. http://www.omniglot.com/language/articles/benefitsoflearningalanguage.htm

Cahyati, P., \& Madya, S. (2019). Teaching English in Primary Schools: Benefits and Challenges. September. https://doi.org/10.2991/iccie-18.2019.68

Chen, S., Zhao, J., de Ruiter, L., Zhou, J., \& Huang, J. (2020). A burden or a boost: The impact of early childhood English learning experience on lower elementary English and Chinese achievement. International Journal of Bilingual Education and Bilingualism, O(0), 1-18. https://doi.org/10.1080/13670050.2020.1749230

Diyanti, B. Y. (2016). Teaching English To Young Learners: Learning Materials. Journal of English and Education, 4(1), 64-81. https://doi.org/10.20885/jee.vol4.iss1.art5

Ernst-Slavit, G., \& Mulhern, M. (2003). Bilingual books: Promoting literacy and biliteracy in the second-language and mainstream classroom. Reading Online, 2003(July).

Gautam, G. R. (2015). Teaching English to Young Children. Journal of NELTA Surkhet, 4(July 2015), 26-33. https://doi.org/10.3126/jns.v4i0.12857

Gawi, E. M. K. (2012). The effects of age factor on learning English: A case study of learning English in Saudi schools, Saudi Arabia. English Language Teaching, 5(1), 127-139. https://doi.org/10.5539/elt.v5n1p127

Glazer, M., Harris, K., Ost, D., Gower, M., \& Ceprano, M. (2017). Creating Bilingual Books to Facilitate Second Language Learning. Journal of Inquiry and Action in Education, 8(2), 81-89.

Hakiki, M. A., \& Hidayati, L. (2017). Is Learning English at an Earlier Age Better for Indonesians? EnJourMe (English Journal of Merdeka) : Culture, Language, and Teaching of English, 2(1), 18-27. https://doi.org/10.26905/enjourme.v2i1.570

Hamers, J., \& Blanc, M. (2002). Bilinguality and Bilingualism Second edition. Cambridge: Cambridge University Press., 1-110.

Hashemi, M., \& Azizinezhad, M. (2011). Teaching English to children: A unique, challenging experience for teachers, effective teaching ideas. Procedia - Social and Behavioral Sciences, 30, 2083-2087. https://doi.org/10.1016/j.sbspro.2011.10.405

$\mathrm{Hu}, \mathrm{R}$. (2016). The Age Factor in Second Language Learning. Theory and Practice in Language Studies, 6(11), 2164. https://doi.org/10.17507/tpls.0611.13

Khairani, A. I. (2016). Pendidikan Bahasa Inggris Untuk Anak Usia Dini. Digilib.Unimed.Ac.Id. http://digilib.unimed.ac.id/id/eprint/448

Lane, J. (2021). The 10 Most Spoken Languages In The World. https://www.babbel.com/en/magazine/the-10-most-spoken-languages-in-the-world

Mustafa, M. C., \& Ahmad, M. (2017). Effective Interaction Strategies In Teaching And Learning of English For Preschool Children. International Journal of Academic Research in Progressive Education and Development, 6(4), 13-40. https://doi.org/10.6007/ijarped/v6-i4/3350

Niah, S., Syahfutra, W., \& Ismanto, E. (2017). Penyamaan Persepsi Pembelajaran Bahasa Inggris Antara Guru Bahasa Inggris Dan Wali Murid Mi Al-Kifayah Pekanbaru. Jurnal Pengabdian UntukMu NegeRI, 1(1), 36-41. https://doi.org/10.37859/jpumri.v1i1.32

Nurjaman, I., Rachmi, T., \& Arjulayana. (2020). Persepsi Orang Tua Terhadap Pemerolehan Bahasa Inggris Anak Usia Dini. Early Childhood: Jurnal Pendidikan, 3(2), 82-90. https://doi.org/10.35568/earlychildhood.v3i2.528

Rahayu, D., \& Apriyanti, C. (2015). NON-EQUIVALENCE MEANING VARIATION IN CHILDREN BILINGUAL STORYBOOKS. http://lppm.stkippacitan.ac.id 
Rahman, M. M., Pandian, A., Karim, A., \& Shahed, F. H. (2017). Effect of Age in Second Language Acquisition: A Critical Review from the Perspective of Critical Period Hypothesis and Ultimate Attainment. International Journal of English Linguistics, 7(5), 1. https://doi.org/10.5539/ijel.v7n5p1

Raman, Garton, Burns, Genesee, Crago, Marinova, Snow, \& J., M. E. J. M. (2011). Teaching English to young learners around the world: An introduction. Bringing the World to the Classroom and the Classroom to Life, 1-22.

https://ngl.cengage.com/assets/downloads/tyle_9781111771379/chapter_1_from_9781111 771379_p02_lores.pdf

Rey, U., Carlos, J., Prieto, J. P., Rey, U., Carlos, J., Rey, U., Carlos, J., Rey, U., \& Carlos, J. (2017). English teaching methodologies for early childhood education Revista Internacional de Didáctica y Organización Educativa E NGLISH TEACHING METHODOLOGIES FOR EARLY CHILDHOOD EDUCATION Jesús Paz-Albo Prieto. December 2016.

Sukarno. (2012). Teaching English to Young Learners and Factors to Consider in DesigningThe Materials. Jurnal Ekonomi Dan Pendidikan, 5(1), 57-73. https://doi.org/10.21831/jep.v5i1.603 